\title{
MY BROTHER HUNTS BEYOND ME (for Michael)
}

On the monument above the river the boys from school play tag

all noon. I am hungry

for you on the other side of the river-

beyond the cliffs and the rollercoaster swooping above them:

for you are learning how to kill animals in a barn, in the woods,

and I am only learning to write about the dragon and the knight.

You come home at times, and once I am taken to visit you,

but you are always running away, and I can never catch you,

and now between my castle and your tent all the waters in the world

seem to spread-no white birds swooping above them. 